\title{
The embryonic cell lineage of the nematode Halicephalobus gingivalis (Nematoda: Cephalobina: Panagrolaimoidea)
}

\author{
Wouter HouTHOOFD * and Gaëtan BorGONIE \\ Nematology Section, Department of Biology, Ghent University, K.L. Ledeganckstraat 35, 9000 Ghent, Belgium \\ Received: 5 December 2006; revised: 1 April 2007 \\ Accepted for publication: 5 April 2007
}

\begin{abstract}
Summary - This paper describes the nearly complete embryonic cell lineage of the terrestrial nematode, Halicephalobus gingivalis, up to somatic muscle contraction, resulting in the formation of 536 cells, of which 24 undergo programmed cell death. Halicephalobus gingivalis has a $94 \%$ lineage homology with both Caenorhabditis elegans and Pellioditis marina, and a fate homology of only $86 \%$ and $78 \%$, respectively. Although $H$. gingivalis belongs to a different superfamily than C. elegans and P. marina, its cell lineage is remarkably consistent with them. Variations in the fate distribution of cells among the different species were only observed at the end of the cell lineage. The data presented here show that the polyclonal cell specification is much more widespread in clades 9 and 10 and is not a highly derived trait that is specifically linked to the fast development of the model organism C. elegans.
\end{abstract}

Keywords - cell lineage homology, embryology, evolution, lineage analysis.

Nematodes are a highly diverse group of organisms with a wide spectrum of morphological adaptations, from interstitial bacterivores to obligate parasites. This diversity allows them to thrive in a wide range of ecological habitats, ranging from deep-sea sediments to arid deserts (De Ley, 2006). However, it is still unclear how the morphological diversity of nematodes relates to their developmental diversity. Most of the current research on the development of nematodes is focused on the model organism Caenorhabditis elegans. Sulston et al. (1983) established the complete embryonic cell lineage of $C$. elegans and showed that a constant number of cells is formed by a fixed division pattern. These authors also argue that, despite the fixed relationship between its division pattern and cell fate, there is no obvious correlation between them. According to Sulston et al. (1983), the tissues of C. elegans have a polyclonal origin - cells that are part of the same tissue are derived from different lineages, which suggests a complex patterning mechanism. More recent studies have shown that these mechanisms constitute a complex mix of lineage-based and organ-based patterning mechanisms (reviewed by Labouesse and Mango, 1999). Bolker (1995) cautions against applying the developmental data of model organisms to other organisms. These data are often biased as a consequence of the criteria used for selecting a model organism. These crite- ria include rapid development and short generation time, developmental canalisation and life history. The study of the embryogenesis of more nematode species will provide insights into the different patterns that form a nematode body plan and how these patterns are linked evolutionarily.

Recent research on other nematode species throughout the phylum has uncovered greater diversity in developmental mechanisms than was previously thought. Most of this research focuses on specific phases or areas of development, such as early development (reviewed in Schierenberg, 2006) or development of the gonad, vulva and male tail (reviewed in Sommer, 2005). Until recently, no detailed, complete description of the embryonic development of any nematode other than $C$. elegans has been available (Sulston et al., 1983). Thus, it remains unclear if these variations in development are part of a different mode of development or fit into the highly invariant ' $C$. elegans-like' polyclonal developmental strategy. Is this cell lineage a highly derived feature, specific to the fast developing C. elegans, or is it a more general mode of nematode development? With the establishment of the embryonic cell lineage of a related nematode, Pellioditis marina, which belongs to the same family as $C$. elegans, we have demonstrated that this cell lineage is conserved

\footnotetext{
*Corresponding author, e-mail: gaetan.borgonie@ugent.be
} 
within clade 9 according to the molecular phylogeny of Holterman et al. (2006) (Houthoofd et al., 2003).

In this study we present the nearly complete embryonic cell lineage of a nematode from the adjacent clade 10, Halicephalobus gingivalis (Cephalobina: Panagrolaimoidea: Panagrolaimidae). This allows us to examine the extent of conservation of this polyclonal embryonic cell lineage in another nematode clade. In most countries, $H$. gingivalis is classified as a free-living bacteriophagous nematode but in reality it is a facultative parasite of horses and occasionally humans (Blunden, 1987; Nadler et al., 2003). We recorded the embryonic development of $H$. gingivalis from zygote to comma-stage embryo with a 4D microscope, followed each individual cell in time and space, established the almost complete division pattern or cell lineage by identifying most of the cell divisions, and fixed the 3D position of almost all cells. This gives us a detailed comparison between these cell lineages on the level of each individual cell.

\section{Materials and methods}

\section{Nematode CUltures}

The soil nematode, Halicephalobus gingivalis JB128, Stefanski, 1954, was cultured on $1 \%$ agar plates with Escherichia coli OP50 as the food source. Culture and handling are as described by Brenner (1974).

\section{D MICROSCOPY AND LINEAGE ANALYSIS}

Early stage embryos were obtained by cutting gravid females in distilled water. One-cell embryos were selected under a dissecting microscope, mounted on a 5\% agar pad, covered with a cover slip and sealed with Vaseline ${ }^{\circledR}$ (Sulston \& Horvitz, 1977).

Three single embryos were recorded at $25^{\circ} \mathrm{C}$ using a 4D microscope (Schnabel et al., 1997; Houthoofd et al., 2003). Every 30 s, 25 focal planes were recorded through the embryo and stored on a laser videodisk. The recording started at the 2-cell stage and continued until the body muscles started to contract. Once muscle contraction started, it was no longer possible to follow the cells between two time frames.

The lineage and 3D displays of each recording were reconstructed using the Simi Biocell software equipped with an automatic collision manager (version 3.5, 4.0, Simi, Unterschleissheim, Germany) (Schnabel et al., 1997). This collision manager automatically detects whether other nuclei are present close to a newly fixed nucleus and greatly reduces the error rate. Since the recording ends at somatic body muscle contraction, it is not possible always to identify accurately the cell type of a given tissue. When discussing the nervous system, no distinction can reliably be made between neurons, sockets or sheaths; this is also the case for cell types of the pharynx.

\section{RELIABILITY}

The lineage presented here is based on three recordings. A consensus lineage was obtained, by which uncertainties of cell positions or cell divisions in two complete recordings were resolved by comparison with the third recording. As the recordings were made only up to body muscle contraction, information about late development is not recorded. In our recordings the consensus lineage contains 571 cells, so the majority of cells present later in the first-stage juvenile have already formed. Although there is some loss of lineage information, most cells have adopted their final fate and position. In C. elegans, 12 late divisions occur after the first contraction of the body muscles; that means the formation of 12 extra cells over a total of 570 cells (or $2 \%$ of the number of cells) (Sulston et al., 1983). The mitoses of some cells could not be resolved in all three recordings and are marked as unresolved mitoses (mitosis was detected but the position of the daughter cells could not be determined). Also the position and/or fate of some terminal cells could not be resolved and are marked as unresolved cells.

\section{NOMENCLATURE}

The cells are named according to Sulston and Horvitz (1977), Deppe et al. (1978), and as adapted by Sulston et al. (1983). Here we summarise this nomenclature to help the reader follow this study. Founder cells formed in the first division rounds are given arbitrary names in capital letters according to Deppe et al. (1978). When a founder cell divides, each daughter is named by adding to the name of the mother cell a single lower-case letter representing its position immediately after division relative to its sister cell. For anterior-posterior divisions, the anterior and posterior daughters are indicated with an ' $a$ ' and 'p', respectively. Dorso-ventral divisions are indicated with ' $d$ ' and ' $v$ '. Left-right divisions are indicated with ' $\mathrm{l}$ ' and ' $r$ '. For example, when founder cell $\mathrm{E}$ divides in an anterior-posterior direction, the daughters are named Ea and Ep. When Ep divides in a left-right direction its daughters are named Epl and Epr. A pair of 
cells may be designated by the use of internal parentheses, e.g., $\mathrm{Ea}(1 / \mathrm{r}) \mathrm{aa}$ means Ealaa and Earaa. In the cell lineage tree the 'a', 'd' and ' $\mathrm{l}$ ' daughters are represented by the left branches, and the ' $p$ ', ' $v$ ' and ' $r$ ' daughters by right branches. Long cell names are split in groups of three letters with spaces to improve readability. For example, the cell ABalaaaaaaa will be noted as ABala aaa aaa.

\section{COMPARISON OF CELL LINEAGES}

Considering the huge amount of data present in any given lineage, we have sometimes opted to include a comparison with the embryonic cell lineage of $C$. elegans (Sulston et al., 1983) and P. marina (Houthoofd et al., 2003) in the results section in order to aid clarity and facilitate discussion. When performing a pairwise comparison between the cell lineages of the three different species, we defined two types of homology. Lineage homology between two species is calculated as the percentage of cells at the time of muscle contraction of one species that have a homologous cell with the same lineage history in the other species. Fate homology between two species is calculated as the percentage of homologous cells of one species that have the same cell fate in the other species at the time of muscle contraction. Some figures, referred to, for example, as 'Fig. S1', are too large to be printed as part of the manuscript and are freely available as supplementary material on the web at: http://www.nematology.ugent.be/develop.htm (see Appendix).

\section{Results}

\section{FIRST DIVISIONS}

The early development of $H$. gingivalis starts with a series of unequal, asynchronous cell divisions, during which a larger anterior somatic founder cell and a smaller posterior germ line precursor cell (P-cell) are formed (Figs 1,2 ). The zygote $\mathrm{P}_{0}$ divides into an anterior somatic cell $\mathrm{AB}$ and a posterior germline cell $\mathrm{P}_{1}$ (Fig. 1A). This germline cell $\mathrm{P}_{1}$ divides into an anterior somatic cell EMS and a posterior germline cell $\mathrm{P}_{2}$ (Fig. 1B). AB divides in a perpendicular direction. After the division of the $\mathrm{P}_{1}$ cell, one of the daughters of $\mathrm{AB}$ migrates to the anterior side of the embryo; this cell will be assigned as ABa. The posterior daughter ABp moves posteriorly dorsally of EMS and leads to the rhomboidal pattern (Fig. 1C). In $H$. gingivalis, the perpendicular division axes of $\mathrm{AB}$ and $\mathrm{P}_{1}$ are clearly visible, resulting in a transient $\mathrm{T}$-shape that immediately converts to the rhomboid configuration (Fig. 1B). The position of EMS determines the ventral side of the embryo (Fig. 1C). EMS divides into an anterior founder cell MS (mainly mesoderm) and a posterior cell E (endoderm) (Fig. 1D). The posterior daughter of the
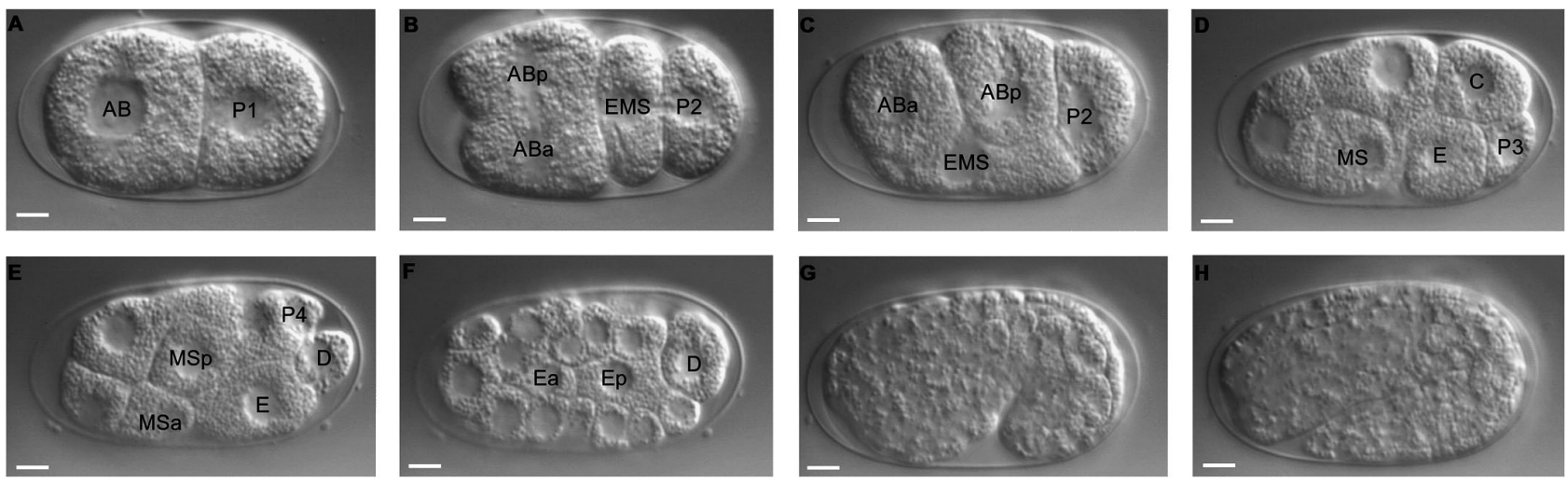

Fig. 1. Nomarski images of Halicephalobus gingivalis embryogenesis. All stages anterior to the left, scale bar = $5 \mu m$. A: 2-cell stage; B: Early 4-cell stage, left lateral view, just after division of $A B$ and $P_{1}$. Note the perpendicular division axes of the two cells, which results in a T-shaped embryo; C: Late 4-cell stage, left lateral view. Rhomboid shape. EMS lies at the future ventral side of the embryo, $A B p$ at the future dorsal side; D: 8-cell stage, left lateral view. EMS has divided in an anterior MS cell and a posterior E cell. $P_{2}$ has divided into a ventral $P_{3}$ cell and a dorsal C cell; E: 14-cell stage, left ventral view. $P_{3}$ has divided in a dorsal $D$ cell and a ventral $P_{4}$ cell; F: 26-cell stage, ventral view. The two E cells lie at the ventral side just before gastrulation, when these two cells move inwards; G: Early comma stage, during morphogenesis (elongation of the body); H: Late comma (2-fold) stage at the onset of body muscle contraction. 

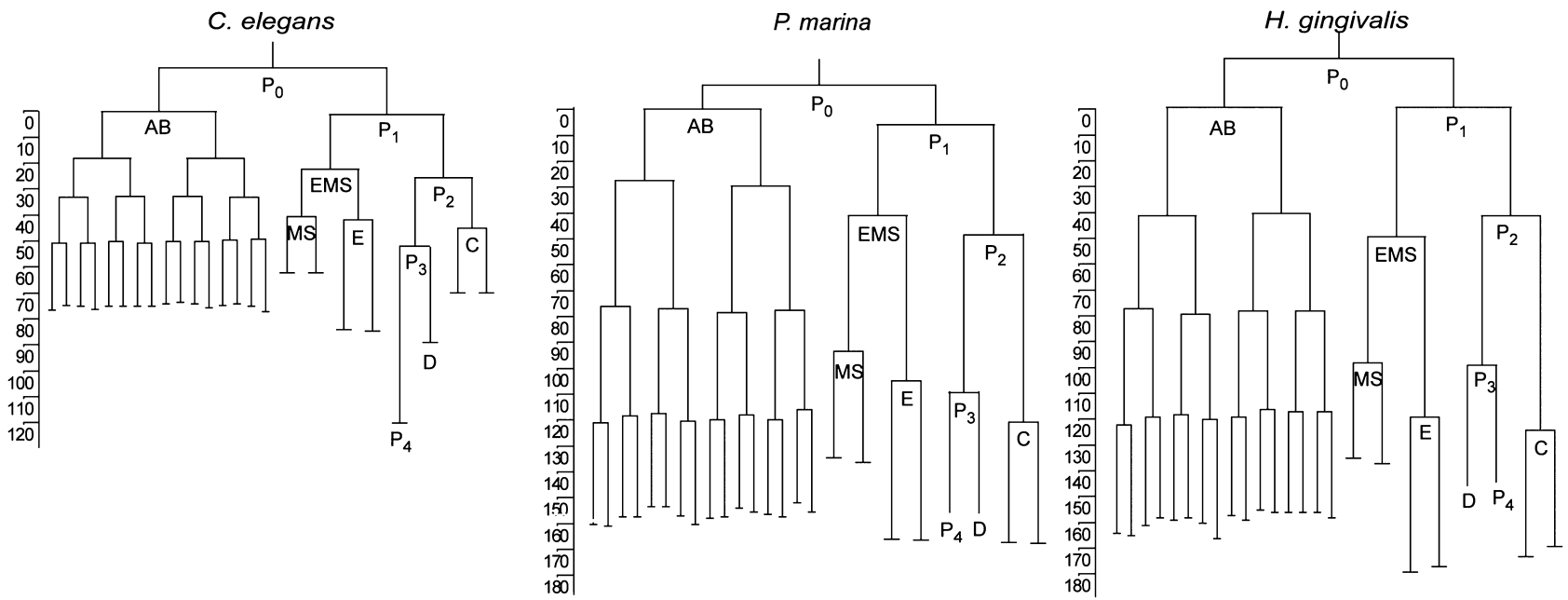

Fig. 2. The early cell lineages and the formation of the founder cells (somatic cells $A B, M S, E, C, D$ and germline precursor $P_{4}$ ). A: Caenorhabditis elegans; $B$ : Pellioditis marina; $C$ : Halicephalobus gingivalis. Vertical axis represents time. Timeline in min after first division of $A B$. The scale of the timeline is equal in all four cell lineages. Note that the developmental speed and the division sequence are different in the three species. Left branch is anterior daughter, right branch posterior daughter.

germline cell $\mathrm{P}_{1}$ is called $\mathrm{P}_{2}$ (Fig. 1C) and is positioned more dorsally from its sister EMS.

In $H$. gingivalis there is a double reversal of cleavage polarity in the germline. At the division of $\mathrm{P}_{2}$, polarity of the germline reverses so that $\mathrm{P}_{3}$ is positioned ventrally from its sister C (Fig. 1D), i.e., similar to P. marina and C. elegans. However, at the division of $\mathrm{P}_{3}$, the polarity reverses again so that $\mathrm{P}_{4}$ is positioned dorsally from its ventral sister $\mathrm{D}$. This is in contrast to $P$. marina and $C$. elegans in which $\mathrm{P}_{4}$ lies ventrally from its sister $\mathrm{D}$ after the division of their mother cell $\mathrm{P}_{3}$. As a result, the cells are orientated from ventral to dorsal: E-D-P $4-\mathrm{C}$ (Fig. 1E). In $H$. gingivalis, the two primordial germ cells migrate in between the two daughters of $\mathrm{D}$, after which they migrate inwards together.

\section{DEVELOPMENTAL TEMPO}

Halicephalobus gingivalis has the slowest early developmental tempo and is 2.9 times slower than C. elegans (Table 1). Subsequently, the developmental rate speeds up so that the period until muscle contraction is only 1.8 times slower than C. elegans (Fig. 3).

In all species, the median cell cycle length of each $\mathrm{AB}$ generation increases during the course of embryonic development (Fig. 4). Comparing the three species, $C$. elegans has an overall shorter median cell cycle length in $\mathrm{AB}$ than $H$. gingivalis and P. marina (Fig. 4). Two different patterns can be distinguished. In C. elegans and
Table 1. Division sequence of the early divisions of the founder cells. Caenorhabditis elegans (Ce), Pellioditis marina (Pm) and Halicephalobus gingivalis ( $\mathrm{Hg})$. The germline cells are marked in bold. Divisions that occur simultaneously or that vary within the same species are separated with a slash. The relative early developmental tempo was measured from the first division of $A B$ and the division of $E$ and normalised with the tempo of C. elegans. The C. elegans data are from Skiba and Schierenberg (1992).

\begin{tabular}{lccc}
\hline Sequence of cell divisions & $C e$ & $P m$ & $H g$ \\
\hline 1 & $\mathbf{P}_{\mathbf{0}}$ & $\mathbf{P}_{\mathbf{0}}$ & $\mathbf{P}_{\mathbf{0}}$ \\
2 & $\mathrm{AB}$ & $\mathrm{AB}$ & $\mathrm{AB} / \mathbf{P}_{\mathbf{1}}$ \\
3 & $\mathbf{P}_{\mathbf{1}}$ & $\mathbf{P}_{\mathbf{1}}$ & \\
4 & $2 \mathrm{AB}$ & $2 \mathrm{AB}$ & $\mathbf{P}_{\mathbf{2}}$ \\
5 & $\mathrm{EMS}$ & $\mathrm{EMS}$ & $2 \mathrm{AB}$ \\
6 & $\mathbf{P}_{\mathbf{2}}$ & $\mathbf{P}_{\mathbf{2}}$ & $\mathrm{EMS}$ \\
7 & $4 \mathrm{AB}$ & $4 \mathrm{AB}$ & $4 \mathrm{AB}$ \\
8 & $\mathrm{MS}$ & $\mathrm{MS}$ & $\mathrm{MS}$ \\
9 & $\mathrm{E}$ & $\mathrm{E}$ & $\mathbf{P}_{\mathbf{3}}$ \\
10 & $\mathrm{C}$ & $\mathbf{P}_{\mathbf{3}}$ & $8 \mathrm{AB}$ \\
11 & $\mathbf{P}_{\mathbf{3}} / 8 \mathrm{AB}$ & $\mathrm{C}$ & $\mathrm{E}$ \\
P4 present & 24 & 15 & 14 \\
Relative early & & & \\
developmental tempo & 1.0 & 2.5 & 2.9 \\
Relative tempo until & & & \\
muscle contraction & 1.0 & 1.7 & 1.8 \\
Number of specimens & 10 & 3 & 3 \\
\hline
\end{tabular}




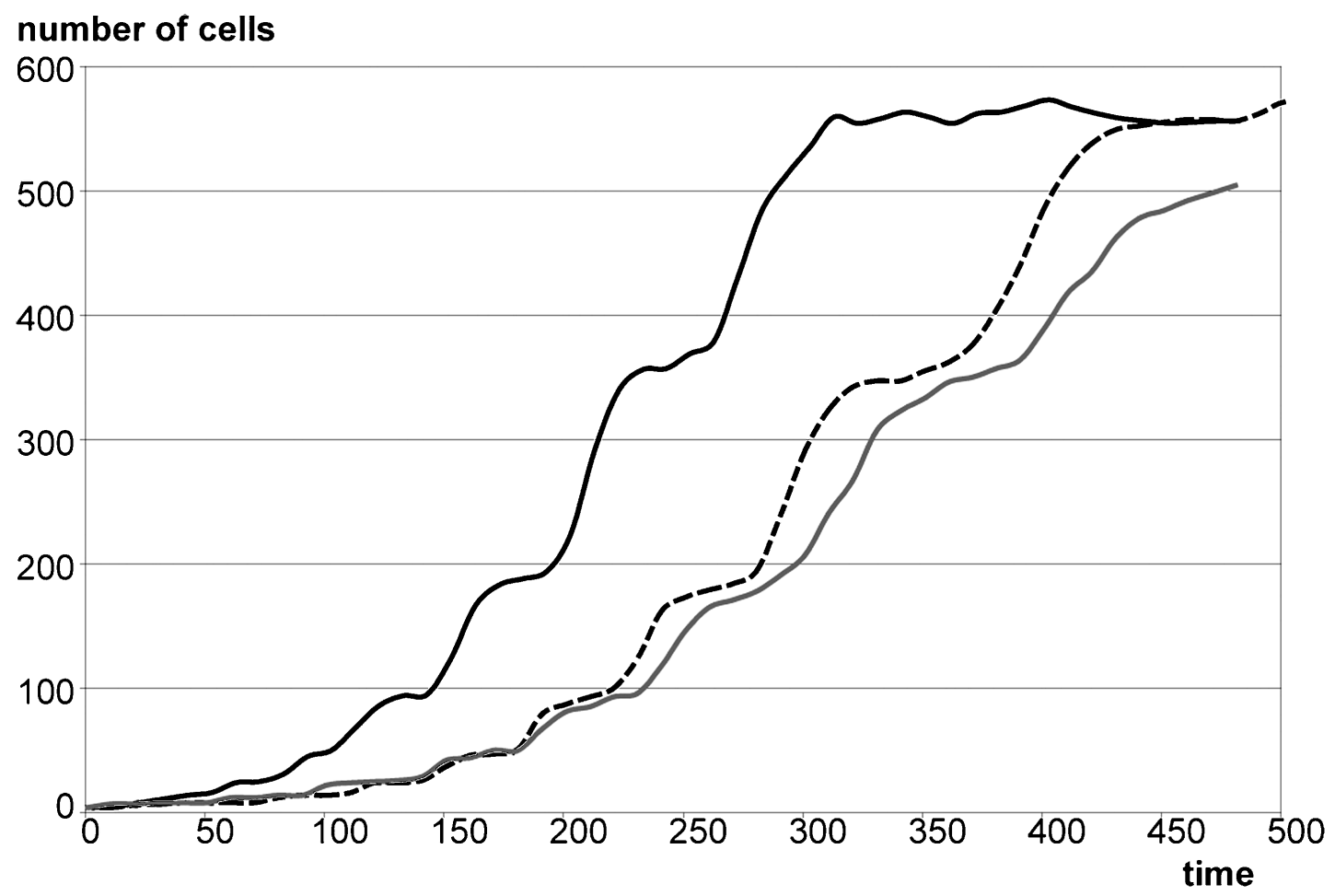

Fig. 3. Number of cells during embryonic development. Caenorhabditis elegans (black), Halicephalobus gingivalis (grey) and Pellioditis marina (dashed). Time in the $X$-axis is normalised from the first division of $A B$. The cell count of $\mathrm{H}$. gingivalis stops prematurely since the precise cell number could not be determined due to the unresolved cells and mitoses at the end of the recordings.

H. gingivalis, the cell cycle length increases slowly at an equal rate. In $P$. marina, the median cell cycle length of $\mathrm{AB}$ shows a peak in cell cycle length at the $4 \mathrm{AB}$ generation after which the tempo briefly speeds up again for two cell cycles.

\section{GASTRULATION}

In $H$. gingivalis gastrulation starts at the 29-cell stage, with the two intestinal precursors, Ea and Ep, which lie ventrally, ingressing to the interior of the body (see Appendix - Supplementary material: Movie S1). Ea gastrulates first at $180 \mathrm{~min}$ in between the mesodermal precursors MSap and MSpp just before the second division round of E. These MS cells gastrulate little after the two daughters of Ea. After the division of E, the two Ep daughters start to gastrulate. Immediately behind these cells, the big D founder cell divides in a left-right orientation and its daughters Da and Dp gastrulate after the Ep daughters. Also, the germinal precursor $\mathrm{P}_{4}$ divides and the two daughters migrate anteriorly between the gastrulating D daughters. The MSaa and MSpa descendants divide anterior-posteriorly and migrate posteriorly over the gastrulating intestinal precursors. Next, these cells migrate into the interior of the embryo. Meanwhile, the mesodermal descendants of C, Cap, and Cpp migrate from the dorsal side to the ventral side and lie on both sides of the two $\mathrm{P}_{4}$ cells. In a final phase, these cells migrate together to the inside as the $\mathrm{AB}$ descendants start to grow over the gastrulating cells.

\section{LINEAGE AND FATE SIMILARITY}

At muscle contraction, the consensus lineage of $H$. gingivalis contains 597 terminal cells (Fig. S1; Tables 2, S1; Appendix). The fate and position of $536(90 \%)$ of these has been determined (the position and fate of 48 cells and the division of 13 cells could not be resolved). The lineage similarity with $C$. elegans and $P$. marina is $94 \%$, and 504 of the 536 determined cells have an equivalent terminal cell in $C$. elegans and $P$. marina (Fig. 5). Fate similarity with $C$. elegans is $86 \%$, i.e., 434 of these cells also have an equivalent cell fate. Fate similarity with P. marina is lower at $78 \%$ (only 


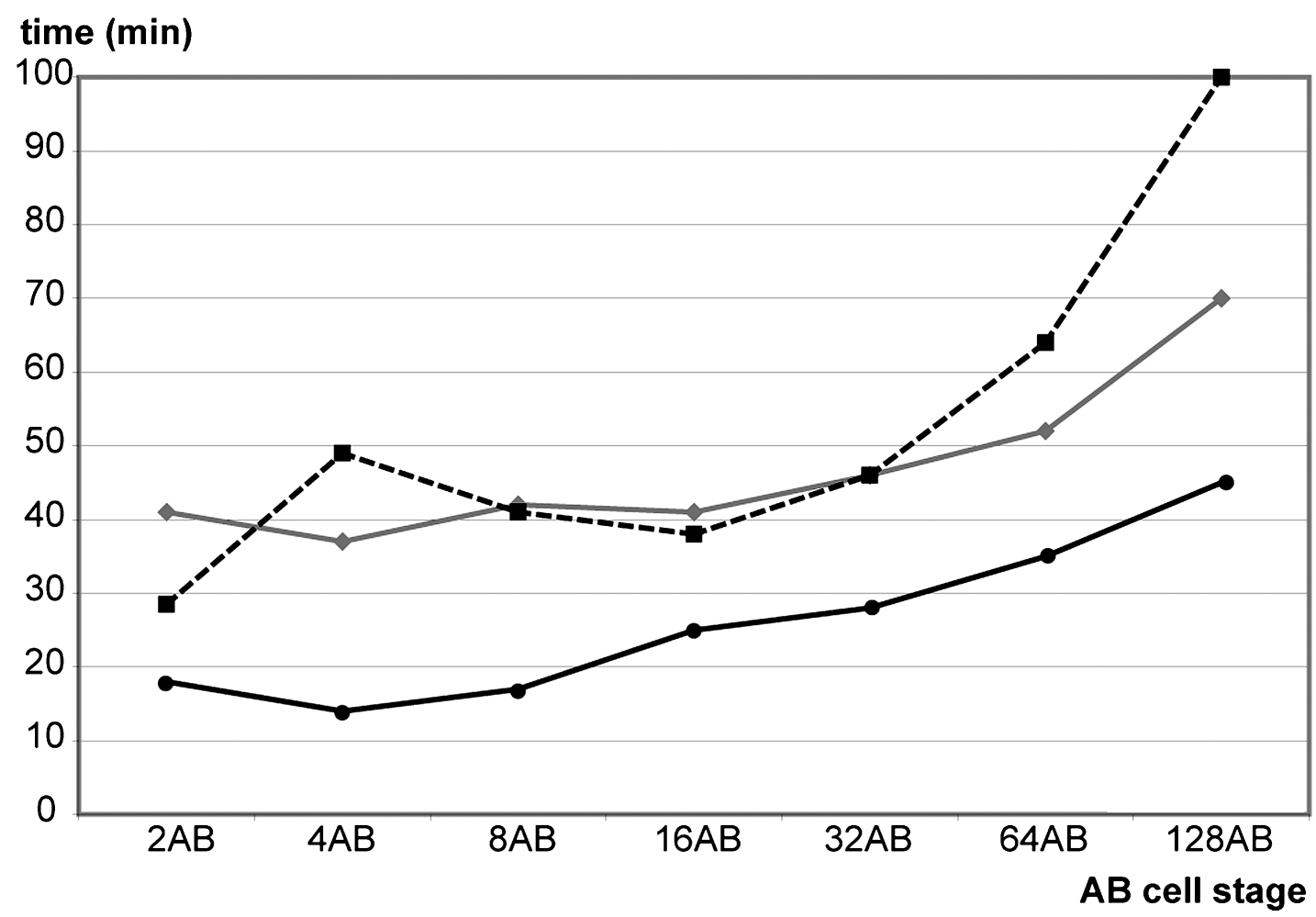

Fig. 4. The median cell cycle length of $A B$ cells in each generation is plotted in time. Caenorhabditis elegans (black), Halicephalobus gingivalis (grey) and Pellioditis marina (dashed).

Table 2. Number of cells per tissue type (row) and founder cell (column). Halicephalobus gingivalis (Hg), Caenorhabditis elegans (Ce) and Pellioditis marina (Pm).

\begin{tabular}{|c|c|c|c|c|c|c|c|c|c|c|c|c|c|c|c|c|c|c|c|c|c|}
\hline & \multicolumn{3}{|c|}{$\mathrm{AB}$} & \multicolumn{3}{|c|}{ MS } & \multicolumn{3}{|c|}{$\mathrm{E}$} & \multicolumn{3}{|c|}{$\mathrm{C}$} & \multicolumn{3}{|c|}{$\mathrm{D}$} & \multicolumn{3}{|c|}{ P4 } & \multicolumn{3}{|c|}{ Total } \\
\hline & $H g$ & $P m$ & $\mathrm{Ce}$ & $H g$ & $P m$ & $\mathrm{Ce}$ & $H g$ & $P m$ & $\mathrm{Ce}$ & $H g$ & $P m$ & $\mathrm{Ce}$ & $H g$ & $P m$ & $\mathrm{Ce}$ & $H g$ & $P m$ & $\mathrm{Ce}$ & $H g$ & $P m$ & $\mathrm{Ce}$ \\
\hline Pharynx & 60 & 79 & 56 & 31 & 33 & 30 & & & & & & & & & & & & & 91 & 112 & 86 \\
\hline Neuron & 199 & 186 & 211 & 1 & 7 & 6 & & & & & 2 & 2 & & & & & & & 200 & 195 & 219 \\
\hline Muscle & 1 & 1 & 1 & 33 & 28 & 28 & & & & 32 & 32 & 32 & 20 & 20 & 20 & & & & 86 & 81 & 81 \\
\hline Epidermis & 74 & 114 & 66 & & 3 & & & & & 16 & 14 & 13 & & & & & & & 90 & 131 & 79 \\
\hline Intestine & & & & & & & 18 & 20 & 20 & & & & & & & & & & 18 & 20 & 20 \\
\hline Other & 18 & 20 & 20 & 7 & 10 & 11 & & & & & & & & & & & & & 25 & 30 & 31 \\
\hline Gonad & & & & & & & & & & & & & & & & 2 & 2 & 2 & 2 & 2 & 2 \\
\hline Mitosis & & & 26 & & & 3 & & & & & & & & & & & & & & & 29 \\
\hline Total survivors & 352 & 400 & 380 & 72 & 81 & 78 & 18 & 20 & 20 & 48 & 48 & 47 & 20 & 20 & 20 & 2 & 2 & 2 & 512 & 571 & 547 \\
\hline Cell death & 18 & 58 & 78 & 4 & 9 & 13 & 2 & & & & & & & & & & & & 24 & 67 & 91 \\
\hline Unresolved mitosis & 13 & & & & & & & & & & & & & & & & & & 13 & & \\
\hline Unresolved cell & 38 & & & 10 & & & & & & & & & & & & & & & 48 & & \\
\hline Total cells produced & 421 & 458 & 458 & 86 & 90 & 91 & 20 & 20 & 20 & 48 & 48 & 47 & 20 & 20 & 20 & 2 & 2 & 2 & 597 & 638 & 638 \\
\hline
\end{tabular}

395 of the equivalent cells in $H$. gingivalis have an equivalent fate in P. marina). Lineage and fate similarity with the other species is probably higher since the fate of 48 cells in the $H$. gingivalis cell lineage could not be 


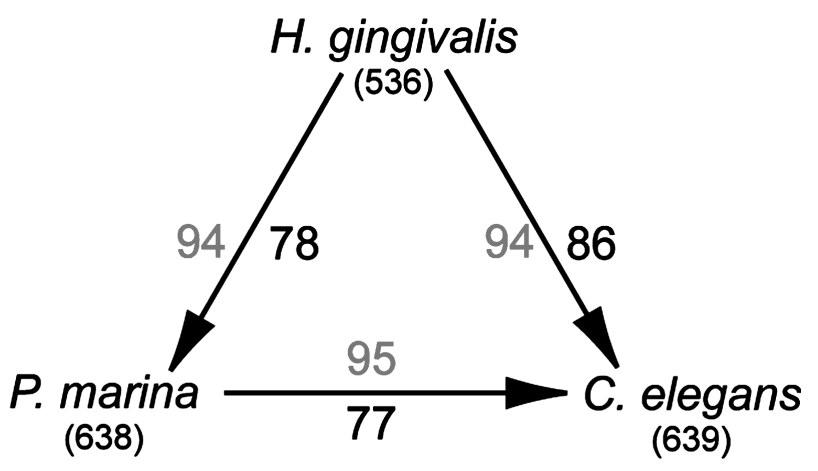

Fig. 5. Lineage and fate similarities between the three species, Caenorhabditis elegans, Halicephalobus gingivalis and Pellioditis marina. Lineage similarity is expressed as the percentage of resolved terminal cells in the first species that have the same lineage history in the second species. Fate similarity is expressed as the percentage of cells of the first species that has the same cell fate as the equivalent cell in the second species. Lineage similarities are marked in grey, fate similarities in black. The direction of the arrow indicates how the comparison was performed. For example, 94\% of the 536 terminal resolved cells in $\mathrm{H}$. gingivalis have an equivalent terminal cell in $\mathrm{P}$. marina. The number of resolved terminal cells in the lineage of each species is indicated between brackets.

determined and the cell divisions of 13 cells could not be resolved.

Despite the marked similarity in development of the three species, individual differences among the different tissues were observed. The primordial gonad, intestine and the body muscles are highly conserved in the three species, whilst the pharynx, the epidermis, and nervous system have a more variable configuration. The following sections will focus on the differences amongst these three species.

\section{INTESTINE}

The 18 embryonic intestinal cells are formed exclusively by the E blastomere. Two E descendants, Eaap and Eapp, undergo programmed cell death. This division pattern differs from the $P$. marina and $C$. elegans pattern although a similar embryonic intestine is formed that consists of nine rings, each built from two bilateral symmetric cells. The morphogenesis of the intestine of $H$. gingivalis and some other close relatives is described extensively in Houthoofd et al. (2006).

\section{PHARYNX}

In the primordial pharynx of $H$. gingivalis, 91 pharynx cells could be identified. Sixty cells are formed by AB
Table 3. The number of cells per tissue type in Halicephalobus gingivalis (in bold in the top row) and the number of equivalent cells in Pellioditis marina (Pm) and Caenorhabditis elegans (Ce), with the same fate (in grey box) or another fate. The grey boxes indicate the number of cells of a certain tissue in $\mathrm{H}$. gingivalis that have the same cell type in the other species. For example, 91 cells have the pharynx fate in $\mathrm{H}$. gingivalis (top row), 64 of the equivalent cells in $\mathrm{P}$. marina also have pharynx fate (row 3 ), while the other 27 pharyngeal cells have other cell fates in $P$. marina (rows 4-9): epidermis (6), neuron (14) and cell death (7).

\begin{tabular}{|c|c|c|c|c|c|c|c|c|}
\hline \multirow[t]{2}{*}{$\begin{array}{l}\text { H. gingivalis } \\
\text { (no of cells) }\end{array}$} & \multicolumn{2}{|c|}{$\begin{array}{c}\text { Pharynx } \\
\text { (91) }\end{array}$} & \multicolumn{2}{|c|}{$\begin{array}{l}\text { Epidermis } \\
\quad(\mathbf{9 0})\end{array}$} & \multicolumn{2}{|c|}{$\begin{array}{l}\text { Neurons } \\
(\mathbf{2 0 0})\end{array}$} & \multicolumn{2}{|c|}{$\begin{array}{l}\text { Cell death } \\
\text { (24) }\end{array}$} \\
\hline & $P m$ & $\mathrm{Ce}$ & $P m$ & $\mathrm{Ce}$ & $P m$ & $\mathrm{Ce}$ & $P m$ & $\mathrm{Ce}$ \\
\hline Phary & 64 & 76 & 0 & 0 & 29 & 1 & 3 & 1 \\
\hline Epidermis & 6 & 1 & 78 & 72 & 25 & 3 & 0 & 0 \\
\hline Neuron & 14 & 1 & 5 & 6 & 132 & 164 & 0 & 1 \\
\hline Cell death & 7 & 11 & 3 & 6 & 12 & 16 & 19 & 20 \\
\hline Intestine & 0 & 0 & 0 & 0 & 0 & 0 & 2 & 2 \\
\hline Other & 0 & 0 & 4 & 1 & 1 & 2 & 0 & 0 \\
\hline Mitosis & 0 & 2 & 0 & 5 & 1 & 14 & 0 & 0 \\
\hline
\end{tabular}

and 31 cells by MS. In the AB-lineage, pharynx cells are exclusively formed by ABalp and ABara (60/60 cells). Also in the MS-lineage, the pharynx cells are exclusively formed by the anterior daughters of MSa and MSp, MSaa and MSpa (31/31 cells). Since the MS cells gastrulate before the $\mathrm{AB}$ descendants, the MS-derived pharynx cells primarily form dorsal pharynx tissue, while the $A B$ descendants form the ventral part of the pharynx. The initial bilateral symmetry of the early cell lineages is still visible in the primordial pharynx. MSaa forms pharynx cells on the left side of the pharynx; MSpa forms cells on the right side. In the AB-lineage the bilateral symmetry is not strict. ABara mainly forms cells on the right side; except for the $\mathrm{AB}$ ara apa lineage that forms cells on the left side along with the ABalp cells.

Comparing the 91 cells that form the pharynx in $H$. gingivalis with the equivalent cell in $P$. marina and C. elegans, $64(70 \%)$ and $76(84 \%)$ of those cells, respectively, also form a pharynx cell (Table 3). In P. marina, 27 of those cells have another cell fate: neuron (14), epidermis (6) and programmed cell death (7). In C. elegans, 15 of those cells have another cell fate: cell death (11), epidermis (1), and neuron (1). For two cells the division of the mother cell could not be resolved in $C$. elegans (Table 3). 


\section{BODY MUSCLE}

In $H$. gingivalis, 86 body muscle cells were identified, i.e., five more cells than in the C. elegans and P. marina embryo. They arise from AB (1), MS (33), C (32) and D (20). However, it was not possible to determine the spatial configuration in detail since not all the muscle cells could be followed until body muscle contraction occurred.

\section{EPIDERMIS}

In the $H$. gingivalis embryo, 90 epidermal cells of a polyclonal origin were identified. They arise from the AB-(74) and C-lineage (16). In the AB-lineage, epidermis cells were mainly formed in the posterior daughters of the ABa lineage by ABalp and ABarp (28/28 cells), and in the anterior daughters of the $\mathrm{ABp}$ lineage by ABpla and ABpra (41/46 cells).

Comparing the 90 cells that form the epidermis in $H$. gingivalis with the fate of the equivalent cells in $P$. marina and C. elegans, $78(87 \%)$ and $72(80 \%)$ cells, respectively, have an equivalent epidermal cell in those species (Table 3). In P. marina, 12 of those cells have another fate: neuron (5), cell death (3), or other cell type (4). In C. elegans, 18 of those cells have another fate: neuron (6), cell death (6) or other cell type (1); for five cells the division of the mother cell could not be resolved.

\section{NeRVous System}

In the $H$. gingivalis embryo, 200 terminal neurons were identified (Table 2). In AB, 73\% of the neurons are formed by ABala (37), ABalp (28), ABplp (40) and ABprp (41). One MS cell, MSa aaa aal, forms one extra neuron. $66-82 \%$ of those 200 neuronal cells in $H$. gingivalis have an equivalent neuron in one of the other species.

Comparing the 200 cells that form neurons in $H$. gingivalis with the fate of the equivalent cells in $P$. marina and C. elegans, 132 (66\%) and 164 (82\%), respectively, of those cells have an equivalent neuronal cell in those species (Table 3). In P. marina, 68 of those cells have another fate: pharynx (29), epidermis (25), cell death (12) or other cell type (1). For one cell the division of the mother cell could not be resolved. In C. elegans, 36 of those cells have another fate: pharynx (1), epidermis (3), cell death (16) or other cell type (1); for 14 cells the division of the mother cell could not be resolved.

\section{Programmed CELl DeATHS}

In the $H$. gingivalis embryo, only 24 programmed cell deaths could be identified (Tables 2, 3). Twenty of those cells have an equivalent cell death in C. elegans and 19 in $P$. marina. Four cell deaths are specific for $H$. gingivalis, one in AB (ABala ppp aaa), one in MS (MSa apa pa) and two in the E-lineage $(\mathrm{Ea}(\mathrm{a} / \mathrm{p}) \mathrm{p})$. In $C$. elegans, the equivalent $\mathrm{AB}$ cell has a neuronal fate; the MS cell divides and its posterior daughter undergoes cell death, and the two E-cells divide to form two intestinal cells each. The 72 cells that undergo cell death in C. elegans but not in $H$. gingivalis, become neurons (24), pharynx (11), epidermis (6) and body muscle (2). The position and fate of 23 cells in the $H$. gingivalis recordings, which have a cell death in C. elegans, could not be resolved, nor could we determine the division of their mother cell (six cells). It is possible that these cells also undergo cell death but this could not be confirmed in the recordings.

\section{Discussion}

\section{REVERSAL OF POLARITY IN THE GERMLINE}

In $H$. gingivalis, the polarity in the germline divisions reverses twice (Fig. 6A-E). The polarity of the division $\mathrm{P}_{2}$ reverses, resulting in a ventral germ cell $\mathrm{P}_{3}$ and a dorsal cell C, as in P. marina and C. elegans (Fig. 6D). In contrast to these species, the polarity of the subsequent germline division of $\mathrm{P}_{3}$ reverses again, resulting in a primordial germ cell (PGC) $\mathrm{P}_{4}$ that is orientated dorsally from its sister D (Fig. 6E). The resulting configuration of the posterior cells is: E-D-P4-C. After the last division, contact between $\mathrm{E}$ and the germline is lost. This phenomenon of polarity reversal in the germline has been described and extensively studied in C. elegans. Experiments in C. elegans, in which the constraining factor of the egg shell is avoided, indicate that during the subsequent germline divisions, $\mathrm{P}_{1}$ and $\mathrm{P}_{2}$ are actually posterior daughters and $\mathrm{P}_{3}$ and $\mathrm{P}_{4}$ are anterior daughters (Schierenberg, 1987). Other variations in the polarity of the germline divisions are found in other species. The cephalobid Acrobeloides nanus (clade 11) lacks a reversal of polarity - all the $\mathrm{P}$ cells represent the posterior daughters, resulting in the configuration E-C-D-P 4 (Skiba \& Schierenberg, 1992) (Fig. 6K-O). Laugsch and Schierenberg (2004) found intraspecific variation in two Rhabditis species, $R$. dolichura and $R$. belari; in some cases, the reversal of polarity is only expressed in the germline division of $\mathrm{P}_{3}$, resulting in the transient configuration E-C- $\mathrm{P}_{4}-\mathrm{D}$. Despite the loss 

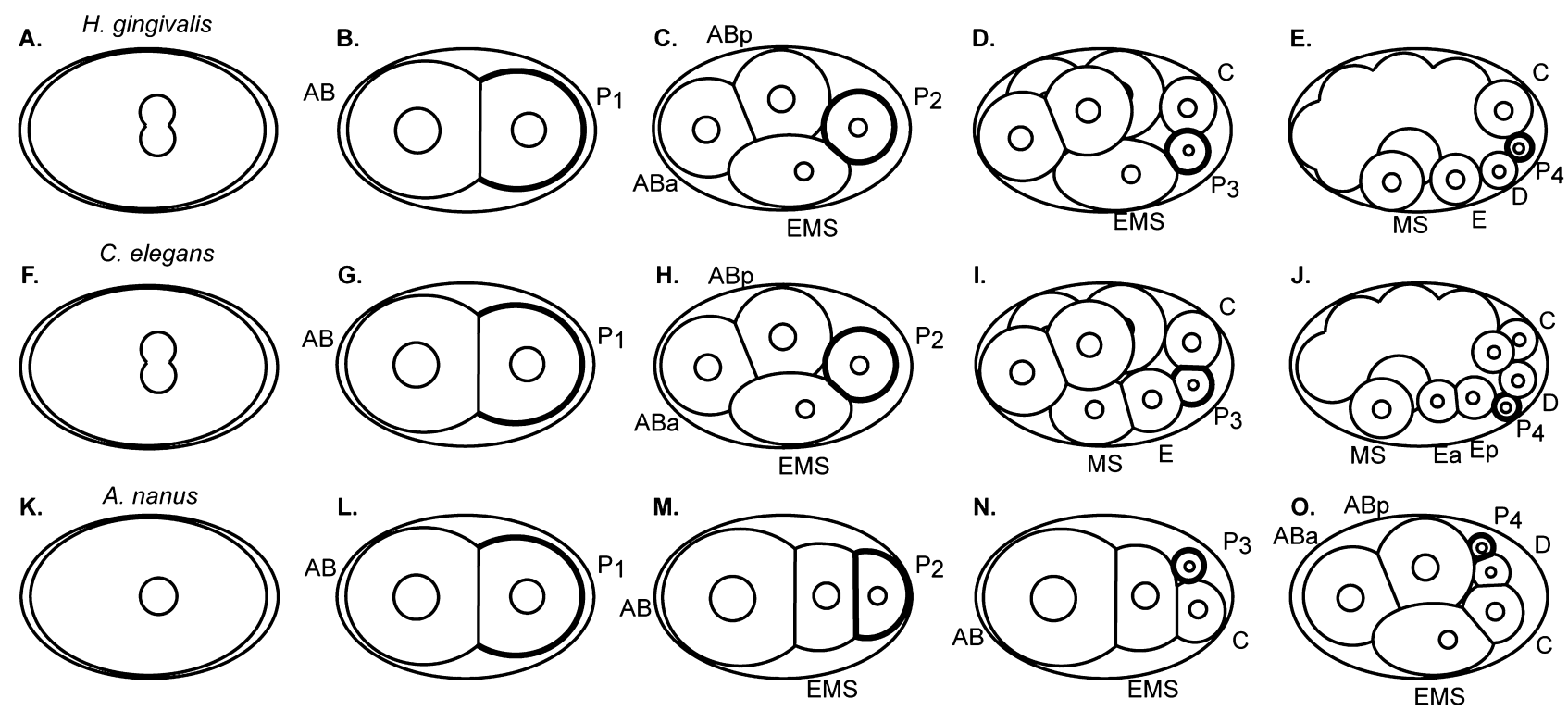

Fig. 6. Drawings of first divisions illustrating the polarity of the germline divisions. Left lateral view, anterior to the left. Big circles in cells indicate the nuclear envelope. A-E: Halicephalobus gingivalis double reversal of polarity in germline divisions. A: 1-cell stage; B: 2-cell stage; $C$ : 4-cell stage; D: 7-cell stage; E: 14-cell stage, the AB progeny is indicated by outline. F-J: Caenorhabditis elegans single reversal of polarity. F: 1-cell stage; G: 2-cell stage; H: 4-cell stage; I: 8-cell stage; J: 24-cell stage, the AB progeny is indicated by outline. $K$-O: Acrobeloides nanus. No reversal of polarity in germline divisions. K: 1-cell stage, only one nucleus due to parthenogenetic development, in contrast with $A$ and $F$, where male and female pronuclei fuse to form zygote; L: 2-cell stage; M: 3-cell stage; $N$ : 4-cell stage; O: 6-cell stage, variations in configuration are possible (Wiegner \& Schierenberg, 1998).

of contact between germline and endodermal line in all these species with partial or no reversal of polarity, this contact is restored before the onset of gastrulation through cell migrations. In $H$. gingivalis, the two primordial germ cells migrate between the two daughters of $\mathrm{D}$, after which they migrate inwards together. In the six-cell stage of $A$. nanus, $\mathrm{C}$ and $\mathrm{P}_{4}$ migrate over the $\mathrm{D}$ cell, and thus they switch places before the onset of gastrulation (Skiba \& Schierenberg, 1992).

Skiba and Schierenberg (1992) postulate that the configuration in A. nanus is the ancestral state and that the polarity reversal observed in the rhabditids is an evolutionary modification on the 'A. nanus-like' configuration, in order to avoid compensatory migrations and to speed up the cell cycle periods and thereby developmental rate. However, recently Lahl et al. (2003) observed a reversal of polarity in $\mathrm{P}_{2}$ and $\mathrm{P}_{3}$ in several species of the Plectidae, an outgroup of the Rhabditida (Blaxter et al., 1998; De Ley \& Blaxter, 2002; Meldal et al., 2007). Furthermore, descriptions of the early development of members of other families from clades I, II and III suggest the presence of small primordial germ precursor cells at the ventral side that contact the intestinal precursor (Malakhov,
1994). Based on the observations of the Plectidae and the other families, one can conclude that this reversal of polarity in the germline, and the maintained contact between the germline and the endodermal line found in $C$. elegans and $P$. marina, is the ancestral state in the phylum Nematoda. Consequently, the variations in reversal of cleavage polarity in the germline found within clade 9 (R. dolichura, R. belari), and clade 10 (H. gingivalis), and the lack of reversal of polarity in A. nanus (clade 11) are derived states that must have evolved independently from the ancestral state in the different branches.

\section{EMBRYONIC CELL LINEAGE CONSERVED WITHIN CLADES 9 AND 10}

A first striking conclusion is that in $H$. gingivalis, cells are built according to a cell lineage that is very similar to $P$. marina and $C$. elegans. The lineage similarities between $H$. gingivalis on the one hand, and $P$. marina and $C$. elegans on the other, are $94 \%$, almost equal to the similarity between $P$. marina and $C$. elegans (95\%). However, fate homology is greatest between $H$. gingivalis and C. elegans (86\%), i.e., 9\% higher than 
between the closely related $P$. marina and $C$. elegans. This indicates that variations in fate similarity do not reflect the evolutionary distance amongst the species. The lower fate homology between $P$. marina and the other two species is mainly due to the different composition of the nervous system and the pharynx, which can reflect specific morphological adaptations to the brackish environment. We only observed variations in the fate distribution of cells at the end of the cell lineage between individual species. With the establishment of the nearly complete embryonic cell lineage of $H$. gingivalis it is clear that the polyclonal cell specification is much more widespread in clades 9 and 10 and is not a highly derived trait specifically linked to the fast development of the model organism C. elegans (Bolker, 1995; Houthoofd et al., 2003). This developmental strategy is very robust, despite the great evolutionary differences and the great genomic diversity in these clades (Parkinson et al., 2004; Mitreva et al., 2005).

However, this robust developmental strategy does not reflect the large morphological and ecological diversity within clades 9 and 10 (Order Rhabditida). Throughout this order, the adult body plan has undergone a wide range of evolutionary modifications that allows them to flourish in terrestrial habitats, e.g., those subject to frequent episodes of rapid de- and rehydration, such as mosses and lichens or extremely xeric and/or cryogenic soils (De Ley, 2006). For example, adaptations in buccal and pharynx morphologies and different food strategies for different adult species must occur late in development after all cells are formed in the first part of embryonic development. During embryonic development, a robust basic body plan, with a pharynx primordium, intestine and four body muscle strings, is built through a stereotyped cell division pattern on which specific adaptations are superimposed during post-embryonic development. For example, a key adaptation within the Rhabditida was the development of a chemically impermeable cuticle that clearly contributed to their success as parasites, colonisers and extremophiles (De Ley, 2006). Cuticle secretion starts after the elongation of the embryo is complete. Another subject of modification in the Rhabditida is the morphology of the pharynx. This diversity mainly involves the evolution of one or more rounded muscular bulbs, which has apparently allowed for more compact body designs. The similar number of pharynx cells among the three species does not reflect the differences in the adult morphology of the pharynx in the three species compared here. Halicephalobus gingivalis has only one bulb in the pharynx, whilst the other species have two. The definitive shape of the pharynx is formed during the second part of embryonic development after most of the cell divisions and after body muscle contractions. On the other hand, the differences in cellular composition of the nervous system among the three species could indicate a possible rewiring of the different pharynx morphologies.

The strong conservation of this polyclonal pattern between the species of clade 9 and 10 suggests that this strategy evolved before the diversification of these clades and played only a minor role in the evolution of faster developing species in these clades. Also, earlier descriptions of the embryonic development of Ascaris megalocephala (clade 3) indicated a fixed polyclonal division pattern (Müller, 1903). This strategy has probably evolved from a slower, more regulative, non-determined development in which cells are determined later in development, as can be found in the basal clades 1 and 2 (Voronov \& Panchin, 1998; Borgonie et al., 2000; Schierenberg, 2005).

\section{Acknowledgements}

We thank Jim Baldwin and Paul Sternberg for the strains. This work was supported by doctoral grants to Wouter Houthoofd by the Institute for the Promotion of Innovation through Science and Technology in Flanders (IWT-Vlaanderen) and funding from FWO (G.0194.03N) and BOF (01104302).

\section{Appendix: Supplementary material}

The following files are too large to be printed as part of the manuscript and are freely available as supplementary material on 'The embryonic cell lineage of Halicephalobus gingivalis' website at: http://www. nematology.ugent.be/develop.htm

Table S1. Comparative cell list of terminal cells with their cell fate between Halicephalobus gingivalis $(\mathrm{Hg})$, Pellioditis marina $(\mathrm{Pm})$ and Caenorhabditis elegans $(\mathrm{Ce})$. $\mathrm{AB}$ cells are grouped per great-granddaughter of $\mathrm{AB}$ and in the names of the cells spaces are left between groups of three letters to improve readability. The fate of each cell is marked with a letter and colour code in accordance with the colour code of the cell lineage figures. blue: neuron $(\mathrm{N})$; green: pharynx $(\mathrm{P})$; purple: epidermis $(\mathrm{E})$; dark blue: other fate $(\mathrm{O})$; grey: programmed cell death 
(D); orange: body muscle (U); brown: intestine (I); gonad (G); unresolved cell (F); unresolved mitosis (M?); mitosis (M).

Figure S1: Embryonic cell lineage of Halicephalobus gingivalis until body muscle contraction (650 min after first division). Vertical axis represents time. Timeline in min after first division. The AB cell lineage is cut of after $490 \mathrm{~min}$, after the last division round, since not every cell could be followed until body muscle contraction. Left branch is anterior daughter, right branch posterior daughter. Terminal cells are coloured according to their fate assignment. light blue: neuron; green: pharynx; purple: epidermis; dark blue: other cell type; orange: body muscle; brown intestine. Programmed cell deaths are indicated by a cross at the end of the line.

Movie S1. Time lapse movie of the inward migration of the intestinal precursors during gastrulation in Halicephalobus gingivalis. Based on subsequent 3D reconstructions; balls represent the positions of the nucleus of each cell. Right lateral view, ventral side at the top. MSa, dark grey; MSp, light grey; E, brown; $\mathrm{P}_{4}$, dark blue, $\mathrm{D}$, light blue. Time is marked at right top corner in min after division of $\mathrm{AB}$.

\section{References}

Blaxter, M.L., De Ley, P., Garey, J.R., LiU, L.X., SCHELdEMAN, P., Vierstraete, A., VANFleteren, J.R., Mackey, L.Y., Dorris, M., Fisse, L.M., VidA, J.T. \& THOMAS, W.K. (1998). A molecular evolutionary framework for the phylum Nematoda. Nature 392, 71-75.

BLUNDEN, A.S. (1987). Halicephalobus deletrix infection in a horse. Equine Veterinary Journal 19, 255-260.

BOLKER, J.A. (1995). Model systems in developmental biology. Bioessays 17, 451-455.

Borgonie, G., Jacobsen, K. \& Coomans, A. (2000). Embryonic lineage evolution in nematodes. Nematology 2, 65-69.

BRENNER, S. (1974). The genetics of Caenorhabditis elegans. Genetics 77, 71-94.

DE LEY, P. (2006). A quick tour of nematode diversity and the backbone of nematode phylogeny. In: The $C$. elegans Research Community (Ed.). WormBook. doi/10.1895/ wormbook.1.41.1, http://www.wormbook.org

De LEY, P. \& Blaxter, M.L. (2002). Systematic position and phylogeny. In: Lee, D.L. (Ed.). The biology of nematodes. London, UK, Taylor \& Francis, pp. 1-30.

Deppe, U., Schierenberg, E., Cole, T., Krieg, C., Schmitt, D., Yoder, B. \& von Ehrenstein, G. (1978).
Cell lineages of the embryo of the nematode Caenorhabditis elegans. Proceedings of the National Academy of Sciences, USA 75, 376-380.

Holterman, M., VAN Der WURfF, A., VAN DEN Elsen, S., VAn Megen, H., Bongers, T., Holovachov, O., BAKKer, J. \& Helder, J. (2006). Phylum-wide analysis of SSU rDNA reveals deep phylogenetic relationships among nematodes and accelerated evolution toward crown clades. Molecular Biology and Evolution 23, 1792-1800.

houthoofd, W., Jacobsen, K., Mertens, C., Vangestel, S., Coomans, A. \& Borgonie, G. (2003). Embryonic cell lineage of the marine nematode Pellioditis marina. Developmental Biology 258, 57-69.

Houthoofd, W., Willems, M., Vangestel, S., MerTens, C., Bert, W. \& Borgonie, G. (2006). Different roads to form the same gut in nematodes. Evolution and Development 8, 362-369.

LABouesse, M. \& MANGo, S.E. (1999). Patterning the $C$. elegans embryo - moving beyond the cell lineage. Trends in Genetics 15, 307-313.

Lahl, V., Halama, C. \& Schierenberg, E. (2003). Comparative and experimental embryogenesis of Plectidae (Nematoda). Development Genes and Evolution 213, 18-27.

LAugsch, M. \& SchierenberG, E. (2004). Differences in maternal supply and early development of closely related nematode species. International Journal of Developmental Biology 48, 655-662.

MALAKHOV, V.V. (1994). Nematode structure, development, classification and phylogeny (translated by G.V. Bentz, edited by W.D. Hope). Washington, DC, USA, Smithsonian Institution Press, 286 pp.

Meldal, B.H.M., Debenham, N.J., De Ley, P., De Ley, I.T., Vanfleteren, J.R., Vierstraete, A.R., Bert, W., Borgonie, G., Moens, T., Tyler, P.A., Austen, M.C., Blaxter, M.L., Rogers, A.D. \& Lambshead, P.J.D. (2007). An improved molecular phylogeny of the Nematoda with special emphasis on marine taxa. Molecular Phylogenetics and Evolution 42, 622-636.

Mitreva, M., BlaXter, M.L., Bird, D.M. \& MCCARTer, J.P. (2005). Comparative genomics of nematodes. Trends in Genetics 21, 573-581.

Müller, H. (1903). Beitrag zur Embryonalentwickelung der Ascaris megalocephala. Zoologica 41, 1-30.

Nadler, S.A., Carreno, R.A., Adams, B.J., Kinde, H., BAldwin, J.G. \& Mundo-OCAMPO, M. (2003). Molecular phylogenetics and diagnosis of soil and clinical isolates of Halicephalobus gingivalis (Nematoda: Cephalobina: Panagrolaimoidea), an opportunistic pathogen of horses. International Journal for Parasitology 33, 1115-1125.

Parkinson, J., Mitreva, M., Whitton, C., Thomson, M., Daub, J., Martin, J., Schmid, R., Hall, N., Barrell, B., Waterston, R.H., McCarter, J.P. \& BlAXTER, M.L. (2004). A transcriptomic analysis of the phylum Nematoda. Nature Genetics 36, 1259-1267. 
SCHIERENBERG, E. (1987). Reversal of cellular polarity and early cell-cell interaction in the embryo of Caenorhabditis elegans. Developmental Biology 122, 452-463.

SCHIERENBERG, E. (2005). Unusual cleavage and gastrulation in a freshwater nematode: developmental and phylogenetic implications. Development Genes and Evolution 215, 103108.

SCHIERENBERG, E. (2006). Embryological variation during nematode development. In: The C. elegans Research Community (Ed.). WormBook. doi/10.1895/wormbook.1.55.1, http:// www.wormbook.org

Schnabel, R., Hutter, H., Moerman, D. \& Schnabel, H. (1997). Assessing normal embryogenesis in Caenorhabditis elegans using a 4D microscope, variability of development and regional specification. Developmental Biology 184, 234265.

SkibA, F. \& SchierenberG, E. (1992). Cell lineages, developmental timing and spatial pattern formation in embryos of free-living soil nematodes. Developmental Biology 151, 597610.
SOMMER, R.J. (2005). Evolution of development in nematodes related to C. elegans. In: The C. elegans Research Community (Ed.). WormBook. doi/10.1895/wormbook.1.46.1, http://www.wormbook.org

SULSTON, J.E. \& HORVITZ, H.R. (1977). Post-embryonic cell lineages of the nematode Caenorhabditis elegans. Developmental Biology 82, 41-55.

Sulston, J.E., SCHIEREnberg, E., White, J.G. \& THOMAS, J.N. (1983). The embryonic cell lineage of the nematode Caenorhabditis elegans. Developmental Biology 100, 64-119.

Voronov, D.A. \& PANChin, Y.V. (1998). Cell lineage in marine nematode Enoplus brevis. Development 125, 143-150.

WIEGNER, O. \& SCHIERENBERG, E. (1998). Specification of gut cell fate differs significantly between the nematodes Acrobeloides nanus and Caenorhabditis elegans. Developmental Biology 204, 3-14. 